\title{
Transition zone: the sequential assembly of its components parallels its dual role in basal body anchoring and ciliary function
}

\author{
A Aubusson-Fleury*, M Lemullois, H Bengueddach, S Abdallah, L Shi, J Cohen, AM Tassin, F Koll \\ From Cilia 2014 - Second International Conference \\ Paris, France. 18-21 November 2014
}

\section{Objectives}

The assembly of cilia can be followed step by step in the unicellular Paramecium, thanks to its predictable spatiotemporal pattern of basal body (BB) duplication and ciliary growth. In order to dissect the process of transition zone (TZ) assembly, we compared the behaviour of several proteins.

\section{Methods}

Combination of EM, immunocytochemistry, protein tagging and RNAi knockdowns.

\section{Results}

Two proteins, FOR20 and OFD1, present at the level of the terminal $\mathrm{TZ}$ plate in ciliated $\mathrm{BB}$, are recruited early during $\mathrm{BB}$ assembly, are required for building the nascent $\mathrm{BB}$ tip where a cap is detected and are necessary for $\mathrm{BB}$ anchoring. After anchoring and before ciliation, a structure similar to the $\mathrm{TZ}$, defined as the pro- $\mathrm{TZ}$, is detected at the BB tip. At that stage, OFD1 and FOR20 are detected at the level of the proximal pro-TZ plate. In contrast, two other proteins involved in the ciliary barrier function, MKS2, and in the axonemal building, IFT57, are detected only at ciliated BB and recruited at time of ciliation in correlation with the extension/maturation of the pro-TZ into $\mathrm{TZ}$. The depletion of these proteins does not affect BB docking.

\section{Conclusion}

1. The assembly of the transition zone proceeds stepwise (building of a cap on nascent BB; differentiation of a protransition zone on anchored non ciliated BB; maturation of the transition zone during ciliation).

CGM UPR3404, CNRS, Gif Sur Yvette, France
2. These steps correlate with the recruitment of proteins required for $\mathrm{BB}$ anchoring and ciliary growth/function respectively, highlighting the dual role of the $\mathrm{TZ}$ in the process of ciliation.

Published: 13 July 2015

doi:10.1186/2046-2530-4-S1-P26

Cite this article as: Aubusson-Fleury et al:: Transition zone: the sequential assembly of its components parallels its dual role in basal body anchoring and ciliary function. Cilia 2015 4(Suppl 1):P26.
Submit your next manuscript to BioMed Central and take full advantage of:

- Convenient online submission

- Thorough peer review

- No space constraints or color figure charges

- Immediate publication on acceptance

- Inclusion in PubMed, CAS, Scopus and Google Scholar

- Research which is freely available for redistribution 